\title{
A COMPARATIVE STUDY OF "ETERNITY" IN THE HOLY QURAN AND THE ANCIENT UPANISHADS
}

\section{Mohammad Reza Afroogh", Ali Reza Khajegir ${ }^{* *}$, and Ali Reza Fahim}

\begin{abstract}
The problem of death and immortality is an ontological concern of human being. Islam and Hinduism, like other religions, have always sought to resolve this problem. Philosophical, verbal, mystical, and Qur'anic criticisms have attracted the attention of Muslim and Hindu scholars. The issue of immortality has been examined from different perspectives. In this study, it is examined from the perspectives of the Holy Qur'an and the ancient Upanishads. The use of the word soul in the Qur'anic verses, and then, with references to the early Upanishads is a key point in understanding the immortality of the human soul. In the Qur'an, special attention has been paid to the issue of the soul and has been referred to as a safe soul. In the Abrahamic religions, human creation is distinctive from other beings, and the final stage of creation is that of human being. In the old Upanishads, only the universal human being (Purusha) is considered as the soul and the main source of the world. The true and inward human being (Atman) is only meaningful in the unity and permanent union with Brahma, and the material aspect of human being (Perkeriti) is not very important.
\end{abstract}

Keywords: Holy Quran, Upanishads, soul, Atman, immortality, Brahma.

* Islamic Azad University, Najafabad, Iran. Email: afroogh100@yahoo.com

** Shahrekord University, Iran. 


\begin{abstract}
Abstrak
Kematian dan keabadian adalah masalah ontologis manusia. Islam dan Hindu, seperti halnya juga dengan agama-agama lain, selalu berusaha menyelesaikan masalah ini. Kritik-kritik filosofis, verbal, mistis, dan Al-Qur'an telah menarik perhatian para cendekiawan Muslim dan Hindu. Isu keabadian telah diperiksa dari berbagai perspektif. Studi ini membahasnya dari perspektif Al-Qur'an dan Upanishad kuno. Penggunaan kata jiwa dalam ayat-ayat Al-Qur'an, dan kemudian, dengan referensi ke Upanishad awal, merupakan kunci untuk mengkaji keabadian jiwa manusia. Al-Quran memberi perhatian khusus pada masalah jiwa dan disebut sebagai “jiwa yang selamat". Dalam agama-agama Abraham, penciptaan manusia dibedakan dari penciptaan makhluk lain, di mana puncak penciptaan adalah penciptaan manusia. Dalam Upanishad lama, hanya manusia universal (Purusha) yang dianggap sebagai jiwa dan sumber utama kehidupan. Manusia sejati dan batiniah (Atman) hanya bermakna dalam persatuan dan kesatuan permanen dengan Brahma, sedangkan aspek material manusia (Perkeriti) tidak terlalu penting.
\end{abstract}

Kata-kata kunci: Al-Qur'an, Upanishad, jiwa, Atman, keabadian, Brahma.

\title{
INTRODUCTION
}

The thought of immortality has been one of the main concerns and questions of mankind, and especially the great issue of scholars of religion and philosophy. A partial look at the arguments of the supporters and opponents shows the importance of this issue, so today; this discussion is one of the serious issues in the philosophy of religion. In the history of religious thought, various approaches have been put forward in various religions about immortality. Looking at the archaeologists' discoveries about prehistoric humans and civilizations in Greece, Mesopotamia, Iran, India, China, Japan, Africa, and South America shows this matter well. The belief in immortality among the people of these civilizations was inclusive (Julen Ries, 1998: 98). The existence of various terms and names to refer to the immortality of man in different languages reflects the fact that there were different views on how human immortality exists. But the question is, what are these thoughts? 
In this study, what is our purpose, the philosophical concept of immortality is not immortality in its customary application, as we say, for example, because the author is forever worthy of his memories. Each of the religions has considered this from their point of view and has tried to take steps to prove eternity. Among all these approaches and opinions, the reasons for the Holy Qur'an and the Hinduism are specific in Hinduism because their arguments are diverse and reasoned, especially as the Holy Qur'an speaks. Typically, there are many people who find acceptance of a matter to be a strong argument to prove it. The issue of immortality has also been encountered in this, and some have also provided proof of the reasons and arguments. In this study, we first look at the history of belief in the soul and its relation to the study of immortality, and then we search and explain the issue of spirit, immortality, and resurrection from the Qur'anic verses. In addition to this review, we will analyze Hinduism's views, especially in the Upanishads, and ask for the opinions of this ancient religion and that book of mystery about immortality. The following important questions about immortality will be examined and analyzed.

Does the Holy Quran endorse and confirm the life of the world after death? How is human creation from the point of view of the Quran and the Upanishads? How does the resurrection of the Holy Qur'an and the Upanishads come from? Source is there? Perhaps we are asked what the reason for addressing the issue of immortality is, if we are to provide a comprehensive and rational answer, firstly, the interest in immortality has grown into human life, and everyone who thinks about this at any intellectual, scientific, and moral level. "Even those who do not believe in religion and religion do not deny their desire for eternity, therefore, with regard to what we have said, we find eternity and discussion (about which one can be related to the happiness and injustice of humans, in so doing, addressing the issue of immortality is an important and necessary thing.

Secondly, believing in a life after death can play a very important role in the person's individual and social temperament and temperament. Some people in the world are looking for prosperity, comfort, and pleasure. Therefore, with the merciful messages of the religions based on the fact that only the righteous will enjoy such blessings, they will try to work in accordance with the orders of the religions to bring themselves to the pleasures of that world, because what is possible in that creature is impossible in this mortal world. Others, whose morale to avoid problems (its other name is "Almighty") and the troubles, try to act in accordance with the laws of God, from the torments that religion has introduced to the wicked. Some people who "Aretaic", when they discover, will come to the brink of virtues by virtue, and the aging of the hierarchs becomes a source of affliction, they live with eternal life. Kant says: "Without regard to the nature 
of the Prophet and the desire for immortality in humans, their morals and concepts disappear (Julen Ries, 1998: 204). Let's not forget that this made Kant the Jewish religion for the sake of the obvious lack of clear references in the Torah to the immortality and the afterlife was rejected and the Jewish religion was forever abandoned. Therefore, the question of immortality, while answering the fundamental questions of mankind, allows the philosopher and the religious scholar to give a clearer picture from the world.

Perhaps the way of burying the dead among the early humans could be a form of belief in the afterlife. They simply buried the dead near the shelter that was in the life of the deceased, and then placed them in the pit of dead marble, ornaments for women and various dishes. In ancient Egypt Perhaps it is possible to say that attention to the cult is one of the most important features of their civilization. The Egyptian people believed that the body would collapse as $\mathrm{Ka}(\mathrm{ka})$ disappears, so life after death is only possible if the body is preserved after death. For this reason, the bodies of the dead were mummified. As the Gilgamesh friends read after hard and difficult events, we find that in the Mesopotamian civilization, how evident is the belief in the life after death? However, the peoples of Mesopotamian civilization are viewed with a negative perception of the afterlife because they thought that every human being after death would go to the infernal underground named "Aralou", responsible for the goddess "Arshigal” (Ereshkigal). The Greek historian Herodotus testifies that the ancient Persians have strongly believed in the life after death. With the advent of the Zoroastrianism in Iran, Tqad immortality another effect change. At various sources Zoroastrian, such as "Gathas" (Gath as), Yasht (yacht), Vandidad (vandidad), and Book of Arda Viraf (ardaviraf), footprint afterlife there.

\section{THE SEMANTICS OF "IMMORTALITY"}

What is learned from this word in its literal sense is that the word "immortality" in Persian is equivalent to the word "khuld" in Arabic and "immortality" in English, it is interesting that all three words mean "eternity". Different texts have different terms for referring to post-death life, such as Yum al-Ba'ath, Yum al-Hassab, Yum al-Qaimam mean resurrection day. It seems that each of these words refers to the particular approach to the issue of life after death, but with a more precise and perhaps more technical look, the word (eternity), we find that this word is a Latin word for eternities, and looks immortality in its affirmative, not the word (immortality) which is in perpetuity in terms of stripping. It means, in the sense of denial, the denial of death, so in this 
discussion we put the greatest emphasis on eternity in the sense of immortality, although we should not forget that the issue of immortality is so different religions are tied together, which is very difficult and perhaps impossible to separate from each other.

\section{Immortality in the Holy Quran and the Upanishads}

It would be strange for many to know that believing in immortality in India has a very long and deep age. The word "amrta" in Vedas, which consists of "a" and "mrta"; means eternity. In "Rig-Veda" human being is considered as dualistic creature. The human has "asu" meaning the agent of life, and "man" means the soul — that which is in the heart—is. The Upanishads have spoken of Atman (Atman), which we call the equivalent of (self). Atman is an immensely human thing that seeks for a supreme unity with Brahman. Human beings, according to what has been done in the past, that is, the work that has been done during his lifetime and referred to as "karma", refers to another body. Here, the good people of Atman are more honorable to the body and Atman, the wicked, enter the lower body of the body. Atman's reincarnation continues in various bodies to the point where he finds merit with Brahman, only in that case, the person becomes immortal. The religion of Islam as an eternal ritual with the issue of immortality, he treats one of the most important concepts. Islamic theologians, according to the Qur'anic verses, are essential to the resurrection of the physical. The religion of religion knows that physical rewards and eagles are possible only in the presence of the body. Allameh Tabataba'i also believes that resurrection is the complete return of objects, but if there is something of a degree then the arrays that are somehow united in the same way are actually returned in the resurrection of all its existence. So the attachment of the human body to his soul is necessary; if the next body is compared with the previous body, then the body of that world is the same as the worldly human body. But if the next human being (with the next body) is measured with the previous man (with the previous body), it will not be like that because the personality of man is to his soul, which is the same in both bodies (Tabataba'i Mohammad Hussein, 1386 [Vol. 17]: 114).

The Qur'an expresses three stages of immortality to man:

a. Restriction: the human soul, after separating from the body, firstly goes to the universe, which is interpreted as a barrage, and continues until the resurrection (Mominon: 100).

b. The rise of bodies from graves on the Day of Resurrection: the issue of resurrection of the human body and the resurrection of being as a definitive principle are expressed in many verses (Adyat: 9, Hajj: 7, Enfetart: 4, Yasin: 51.52 and 78.79) 
c. The body of the Awakened according to the hereafter: according to the verses concerning the punishment of the infiltrators, it is obtained (Nisa: 56), that the body of the world's afterlife conforms to the world of the hereafter, because it does not have corruption and destruction. If we look at the verses of the Holy Qur'an, we will find that humans never die after death. But their life begins in another world. In chapter of Imran, verse 169, it is stated: "And those who are killed in the cause of Allah will never be dead, but they are alive and given to the Lord." In addition, in the chapter of Mu'minoon, verses 99 and 100, we read: "When the death comes to one of them, he says: "My Lord, may I return to the earth, I may do the good deeds that I have left. Never, this is the saying that he says and behind him is a shrine until one day." Which get excited?

In the Holy Qur'an, the two words "paradise" and "hell" have repeatedly been repeated; the place of the devotees of Jinnah and the place of the torment of the perpetrators of hell has repeatedly been mentioned in the Qur'an, why? The Holy Qur'an responds to itself, saying: "The worldly world is at an end, and then another world begins." It comes from the verses of the Qur'an that on the Day of Judgment, which is finally the worldly world and the beginning of another world, there is a stirring up of chaos (Nazeat of 79 verses: 6-9), Forghan 25, the verse 25 and in the various verses of the Holy Qur'an, reference is made to the attributes of paradise and its blessings, as well as the attributes of hell and its punishments. For example, according to the verses of the chapter, events on the Day of Resurrection are divided into three categories: the holy places of God, they have a great value. They are located at lower levels, in paradise with cedar trees and bananas with permanent shadows. Associates of the north live in poisonous and poisonous winds and a shadow of black smoke that is neither cool nor good. The fact is that there are many arguments and unimaginable images in the Holy Qur'an that there is another world and the life after death that the verses of Allah will be more precise in the later sections.

\section{The Immortality of the Soul}

\section{a. The immortality of the soul in the Holy Quran}

What is certain from the point of view of the Holy Quran and the religion of Islam, man is the supreme creatures of the world and the best fruit of the tree of creation, for which he created the existence for his sake and placed earth and time in the realm of his caliphate. The Lord created the human world with his own hand from a certain flower and blown in his body with a special spirit. "It was so that your Lord said to the angels," I am the human creator of the 
flower, so when we fixed him, and in it I swallowed my spirit to fall into prostrations! (chapter of Sad, verses 72-71) (The Holy Qur'an explicitly tells us that the status of man is the divine caliphate and the succession of the Prophets to this earth, and he is the superior person of all angels). In the chapter of Baqarah, verse 3, we read that "We created all that is on earth for you, o Man!" It is understood from this verse that God placed man in his royal authority, that is, gave him authority and authority in order to the earth deals with it, but what is there in the earth and the heavens is for him, and can be conquered in his captivity if he tries and wants. On the other hand, the story of the angels, the obedience of the devil, which was not of angels, but had a dignity like them, caused the devil to be rejected and his great punishment would be resurrected (Chapter of. 85-73). This is an indication of dignity unmatched and righteous is man, where we read in the chapter of Thin, "We created man in the best of conditions, and then we brought him back to the lowest places, except those who believe and do good deeds, which is a reward without any shortcomings and fines for them (chapter, Tien, 6-4). That God created man from a certain flower and breathed into him from his special spirit in the eyes of the mystic, is considered to be God's will is that human being passes the way of perfection to the heavens and God created man free made it possible to go on the road of knowledge goes after, to promote and to know that many of the creatures of virtue and superiority. The Holy Qur'an says: “And, verily, we have honored the sons of Adam, and we have brought them on the land and on the sea, and we have given them good things to them, and We have exalted them" (Excerpts of verse 70), of all that is stated and presented as an example. From the verses of the Holy Quran in this regard, we wanted to conclude that all these great human authorities and the unique cremated to him in the field of existence are due to the fact that God in his body and in his material body has a special soul It was blowing and made him really a god and a heaven. In the next section, with the various forms and forms of the word, we will become more familiar with the soul and soul. We will see the creation of mankind He examines in two cases one that explains the human being and his creation from the soil and mud or the spleen and its evolutionary stages, and the one that gives the human being another truth from which he interprets the spirit and sometimes the other people.

The Holy Qur'an says: "We gave man the perfect creation" (Mu'minun, verse 14). This second creation is nothing but the creation of human life that does its soul, or elsewhere, it says: "We send him our special soul"( Hajar, verse 29), when I finished it and breathed it into my soul. With a little reflection and thought in these verses, we find that the existence of the soul in the Holy Qur'an is definite. It is also mentioned in these verses to some aspect other than the physical and 
material aspect, although the creation of that truth is another, the same spirit as the completion of the material aspect of the human body, of course, we do not think in any way that they believe in human creation as the product of mechanical and material interactions, and we believe in something else. On the other hand, it is emphasized in the teachings and religious teachings that the Lord of the world to human beings it is very close, closer to anything. Therefore, it is necessary for man to be aware of such a kindness and proximity, and so close his own self to the holy nature of the righteous, in connection with which his high rank, his strength, his dignity and majesty to understand. Now the question is, is God close to the human body or to his soul? The Holy Qur'an responds. "And it is the true verses of the poor and the evil one" (verse 85). That is, we are closer to him than you, but you do not have knowledge and insight, which is here open to the existence of a soul that is invisible and joyful Invisible, for the sake of greater certainty, after the same verse that has just been mentioned, it is necessary to pay attention to the chapter of the event, because exactly in verses 86 and 87 , the existence of the soul as a true thing that man never can the body of the dead body is referred to.

\section{b. Levels of Soul in the Qur'an}

In the Holy Quran, the word "soul" - which comes from that source of life- has come repeatedly, and it does not seem to matter in humans and animals alone, but in the case of the other two clans, for example, in the verse "We sent to you our soul" (Mary, verse 17), and in the verse, "and the Spirit is ours and dependent on us" (Salvation, verse 52), and in other verses in non-human beings and animals, it turns out to be the soul has an instance in man, and another case in non-human. And in the Qur'an what is competent is the revelation of the soul. The point in the verse, "And they ask you about the Spirit, say the Spirit is from my God" (Isra., verse 85), which we see is absolutely he brought it in no way, and in front of him, he said: "The spirit is from the deeds of God, then it is the duty of God elsewhere that if our cause turns on it, it will change it and God is pure and pure" (Jas, 82, 83), saying that he is the very word and the command of creation, which is, but is not, because it is a documentary about the apparent causes, but because it is attributed to God of excellence And his resurrection is upon him. And this is why he introduced Christ (peace be upon him) as his unclean ways without having a father to Mary, saying: "And the word of God is from God sent to Mary "(Nisaa, verse 171). And moreover, this is the same verse, which states: "It is true that the extravagant nature of the creation of Jesus (AS) is like the wonderful creation of Adam, that God has filled humanity to perfection. It was the same that God had commanded" 
(Al-Imran, verse 59), because in this verse the story is likened to the story of Adam. He should say that God is Almighty, although he has mentioned this word in most of his words with adjectives and adverbs, for example, "We breathed from our soul in Adam" (Hajj, verse 29), or he said: "And he is from his own soul in the Adam, he breathed" (Sajdah, verse 9), or he said: "And we sent our souls to him" (Mary, verse 17), or he said: "And the Spirit is from God" (Nisa, verse 171), or said: "And we helped him with a pure spirit" (verse 87), and other verses (translated into "my soul”, "my soul”, "soul”, "spiritual from him", "the Holy Spirit”, etc.). But in some cases, he has unequivocally stated, for example, "We send us angels and souls to him" (Magnanimity, verse 4), which appears from its appearance, is the soul of an independent being and a celestial and nonangel creature. And like this verse, the following verse is said that the angels and soul of Al-Amin will rise to receive the command of God to the throne of God on the day when it will last fifty thousand years (Exaltation, verse 4).

But the soul that belongs to man is interpreted as "I am spiritually—from my own soul" or "I am spirit-from my own soul", and in this sense, the word "I" has come to mean that it refers to origin, and also interpreted the meaning of its belonging to the human body, and from the spirit that was special to its believers, like the verse, "And we have helped him through the Spirit" (controversy, verse 22) or interpreted in that letter "Baba", which implies affirmation, confirms and strengthens the spirit, and relieves the soul of the particular one, such as "We helped him with the spirit of Al-Amin" (Baqerah, verse 87), interpretation of soul to the word "Qods", which means the purity, and this also confirms real prophet and his great dignity.

And if we add the Qur'an verse to these verses, then it turns out that the proportion of the soul in these verses with the absolute soul in chapter of Zadr is a proportion that is intent on shining with something that is shadowed by God's permission. And also the soul belonging to the angels is from the permission of the soul to the permission of God, and if he does not interpret the spirit of the kingdom, and in the case of man, he has given these two interpretations to the angels: "We send our special soul to him."

Or "We have sent down to him the soul of Al-Amin" (Shoara, verse 193), for the reason that the angels, with all the differences that are in the glory of God and after God, are spiritually pure, and if they are, presumably, physical in the eyes of people is a representation that takes on themselves, rather than to have a true body and head, as we see in the story of Mary (PBUH): "We have our very supreme soul We have sent a very beautiful image to the Prophet" (Mary, verse 17), and we in the past, in the same verse, discussed allegory in the same verse. 
Unlike humans, which is not a mere soul, but an being composed of a dead body, and a living soul, then it is appropriate for him to do the same as to interpret it to bloat, as in the case of Adam: “And say: Allah is from His Spirit. Blow in man” (Gen., verse 29).

And as the difference of spirit in the creation of the angel and man caused a different interpretation, and did not interpret the angel's bloating, also the difference between the soul's soul, which has different degrees of honor and fatigue, has caused the interpretation of belonging. It will be different, one will interpret the word, and will confirm another place of interpretation, and consider the spirit to be different in terms of the difference in its work.

Indeed, there is a spirit that blooms in humans, and says about it: "And breathed from her soul in him," and another soul is called the Spirit of Confirmation, which is a special believer, and says: "And God wrote the light of faith on their hearts and helped the glorious spirit" (Controversy, verse 22), which, in terms of honor in its nature and in terms of the virtue of its work, is sharper and stronger than the spirit that is in all living beings, Testifying that in the following verse, which is in dispute in the meaning of the verse of this chapter, says: "And we, who did not know, led the light of the guidance of the knowledge and we help him by our special soul."

You see that in this verse, the believer has alive a vital light, and he believes the infidels, although he lives, dead and lacking that light, then it turns out that the believer has a spirit that does not disbelieve it, and the believer has the effect that In the spirit of the disbeliever.

From this, it turns out that the spirit has different levels; one stage of the spirit is the stage in the green plants, and its effect is that it grows the plant and the tree, and the verses indicate that the earth was dead, and we have resurrected a talk about this spirit. Another stage is the spirit of the spirit through which the prophets are confirmed, and the sentence "And we helped him with the Holy Spirit" (Bagherah, verse 87). And the verse of the verses indicates that this spirit is more glorious and has a higher level than the human spirit.

\section{THE MEANING OF ATMAN IN THE UPANISHADS}

Before discussing human creation, let us talk a bit about the creation of being in the Upanishads. In the Upanishads, there are many gods that they are the first causes of creation, these gods sometimes have one and the same role, and sometimes even their names are used. Sometimes these gods are equally or sometimes superior to one another. By the way, they created espionage, 
followed by the agility of other gods. Of course, the problem of creation in Hinduism is largely ambiguous and not sufficiently coherent. But in general, the philosophers of this religion admit that, in fact, the plurality of the world depends on a single entity, Brahman. In Mundika Upanishad we read: Brahman is expanded with the power of concentration and meditation. Then material emanates from the material of life, mind, wisdom, the seven worlds, and the work that is done in the universes, is an endless sequence of works and outcomes. But human creation, in the eyes of human oppressions, mankind has the two dimensions are material and immaterial, that is, in other words, it has an object and soul, "The human being is the individual whom we call the Jive Atman, and on the other hand we have the general or cosmic universe we call it Para Atman" (svet. Up.4.6). In the Upanishads, the relation between the origin of man and God, and that man is perceived to be a child of God in some way or another, is said that God created man from his element or nature (Brhad., 5.2.1), which means that Angels or gods; human beings and demons who are descended children, but what is Purusha (purus) in the Upanishads refers to a different concept of man and sometimes atman, meaning what is in the heart of the sanctuary That is, the soul or soul of a person who is undergoing another stage of biological process (Rhdhakarishnan, 1997: 90). When man's death comes, Purousha, along with other forces At the end of this section, it should be said that in the Upanishads, if the purosha is likened to fire, sun, wind, etc., (Svet, p. 4.2), it means the unity of Atman and It is Brahman that there is nothing besides Atman, namely Poursha, and that which is the same. In previous discussions, we talked about the word of the Spirit in the Holy Qur'an, but if we ask about Atman and his creation in Upanishads, We must say that to understand Atman, the material body of man and his organs are brought as allegories (Brhad. Up. 2.2.1-4)! The difference of the body with Atman may be that it should be noted that, as long as the human body lives, it is the place of Atman, and Atman belongs to the object, but when human death comes, Atman is abandoned (Ch. 1). In the Upanishads, when it comes to Atman, the word "self" actually appears, and Atman, who is immortal and immortal in man, always seeks for unity with Brahman. The rhetoric of Athenian's self-expression, often appearing in the Upanishads, often refers to the inner soul and the essence of the sensuality that is unrecognizable and completely distinct from body and body. Brahma is in the same general sense, and Atman, the so-called "impersonal" spirit, both of which is a sacred soul and ultimate truth, from which is referred to as "Brahman-Atman", and both the posture and the inner being are in fact one and the separation do not have the same as in the Sanskrit language, “Tet Um Sisi” (Chand .8.6.8.6) means you're. 


\section{Atman's Degrees in Upanishads}

In the rich treasures of Hindu religion, in the Spirit or Atman discussion at the beginning of the work, we are dealing with another term that applies to the supreme or supreme principle, the Atman. The supreme principle has two aspects: on the other hand, superior, sublime, and glorious of all objects, and on the other hand it must be its present, appearance, and environment on all beings (Schuon, 1991: 81). When the words of Brahma and Atman apply to the Supreme Principle, they refer to both aspects, but the notion of transcendence is more closely linked to Brahma's word, and the notion of surroundings and presence is more associated with the word Atman, which is why Shaun says: "Maya Atman" or "is not the other" (Peasant, 442: 1384). In the world of thought, the first is "purification" and the second aspect is "likeness" (Reza Zadeh Shafagh, 1365: 40-20). In the Upanishads, we read: "He who dwells in all things but does not know all things, besides all things, his tone is all things. He runs all things from within himself - he is your breath, the director is inner and non-mortal" (Brih. Up. 3, 7, and 15).

From the standpoint of Hinduism, the truth is in the same unity and unity with many degrees, that is, the truth, a degree of severity and weakness, whose plurality returns to unity. We can summarize these levels in five ways: (1) the degree of divine nature or the supreme principle referred to by the words of the Atman and Brahma. This is the same Brahma without the attributes of attributes that are called supra or "Brahma Nirguna": "The one, who is colorless, in practice, distributes his power with his own secret will to different colors. And the first and the last of the universe is dissolved in him-he is God" (Shve. Up, 4. 1). (2) The existence of the word "Ishvara" refers to it. At this level, God is referred to the attributes and in the sense of the "personal God". This time is equivalent to the degree of virtue or theology in Islamic mysticism. But from these two passages, we consider the manifestation of God in three times, which is: Almighty, The universe of the world and the universe. (3) The order of the universe of intellectuals referred to by the word "Being" is referred to as "soul" or "holy intellect" (Peasant, 37: 1384). (4) The world of the soul, which forms the mediator between the world of bodies and the world of intellectuals, is referred to in this universe by Hindu religion. (5) The last time is the very body of the bodies, which is called "stoic". In Upanishads, man is defined as a "minor world" or "complete communion". Man does not belong to any of the levels and in the sense of all the levels it is summarized. Because man is one of the manifestations of God in manifestation, the manifestation of mankind has appeared in his body, soul, and reason, respectively, three times in sequence, but because man is "omnipotent", in addition to three manifestations, the spirit, the 
soul and the first twofold object of the five is also the corresponding man. Corresponding to the first order, or Brahma Nairgona, there are a variety of people referred to by the term "Atman", and corresponding to the second order, or Brahman Saguna, is also ranked "Jiva" (Shaygan, 1362.2: 816).

\begin{tabular}{|l|l|}
\hline \multicolumn{1}{|c|}{ Great Universe } & \multicolumn{1}{c|}{ Minor Universe } \\
\hline $\begin{array}{l}\text { Nirguna } \\
\text { 1. Brahman }\end{array}$ & Atman \\
\hline Saguna \\
$\begin{array}{l}\text { 1. Brahman } \\
\text { 2. Ishou Vara }\end{array}$ & Jiva \\
\hline
\end{tabular}

"Atman" is the truth we call "self", that is, the fact that the pronoun, essence and joke form the truth of ours. But "Jiva" is the level of human determination. In Upanishad, it comes as follows: "You could not see the viewer, the listener could not hear, you cannot understand the understanding, this is the Atman that is in all this" (Brhad, Vp. III, 3, 3). In this text, emphasis is placed on the authenticity of Atman and his surroundings on all human elemental elements. Thus, as the principle of the universe is present in all its forms and manifestations, and there is no place for it to be empty, the principle of human truth is manifested in all its prophets and its actions.

\section{Atman's Eternity}

In the past, we have said that the Upanishads have spoken of Atman, which is equivalent to the word "self". Atman is an immensely human thing that seeks for a supreme unity with Brahman. The expression of the breath of runners to Atman, often appearing in the Upanishads, often refers to the inner soul and the essence of the senses that are unrecognizable and completely different from body and body.

Here is the question of what the so-called "soul" or ego is? The interpretation of the soul or the ego is the same truth of the unconventional real essence and essence that lies in the human body. We see many parts of the Upanishads that, contrary to what people have said and say that the spirit of humanity is individuality and independence, the Upanishads tell us that there is a common identity or unity between Brahma and Atman, and all the people in all appearances and their manifestations are Brahma. Arnica says: "Tell me, who is the emergence and manifestation of Brahma that is beyond our insight and insight, that the soul is everything." And he himself replies: "He is your soul." 
All of these statements give us the general result that the human soul and cosmic spirit, or the "world of the world", called Para Atman, are not the same object and separate, and in the Upanishads the meaning is interpreted as Sanskrit "Tet Um-osi" means "You are Him" (Birth. 3.7.1.23). Brahma, the universal entity of Athena, the soulless individual soul, both of which are the sacred soul and ultimate truth. From which it is referred to as "Brahman-Atman." Both the posture and the interior of the two are the same. The truth is that, if there is a fair comparison between the Upanishads and what is going on in Behgavad Gita, we find that, of course, the issue of immortality has come from the Upanishads (Shayegan, Darius 1/323, religions and philosophical schools). In the Upanishads, it is clearly expressed in the immortality of man, where it says "the deterioration of the body and the immortality of the soul" and it expressing the tree and soul with the allegory. What is your temperament? $(6,11-12)$. Death finds tone, but the perfect soul is unchangeable and unlimited. In the new era, a new theory has emerged in Upanishads, which states: "Finally, any distance from the world of time, Kalpa, which is the period Creation and creation is about to end" (John Noss, 86: 154). Once upon a time, all ghosts in the universe are separated from the bodies, and at one point it is fixed, and after a long period of silence, Peralaya is re-creation of the Creation: the universe is alive, and the souls, who are in silence and stillness, are brought to the movement. All the creatures, from plants and animals to humans and demons, are in new bodies and faces are replaced. Yes, these bases and thoughts that were found in the Upanishads as the first and foremost nucleus later revealed themselves in the form of the philosophical schools of India.

\section{COMPARE THE CREATION OF THE SOUL IN THE HOLY QUR'AN AND THE UPANISHADS}

What is certain is that the creation of man in the Holy Quran is expressed in a completely realistic and wise view. In addition, Islamic scholars and intellectuals have given a philosophical and realistic account of the verses related to man and his creation to interpret the position of man and his creation. Concerning the issue of the soul, the situation is similar in Islam and the Qur'an, that is, since the soul is in contradiction to the material structure and the principles governing it, other than the principles of this book: "The soul is from his world", it means that the Soul is from God and has a mysterious creation.

The Prophet (pbuh) even explained later on the soul, saying: "Your competence in knowledge and science is low, so it is not a wonder that you do not understand the mysteries 
of the soul, although everything is closer to you" (Makarem, 1387: 254). Allah the Exalted, as He wants to depict the inability and disability of the unbelievers and the disbelievers in the divine essence, says: "If you are truthful, you will return the (soul) to the dead man" (chapter of Vagheha, verse 87). The truth is that, given the explicit reference of the Quran to the inability of man to restore the soul to his body, Allah Almighty has called for the complexity of the Spirit to be expressed even to man, the highest creatures and most prominent beings. Introducing the human being as an unparalleled greatness that separates us from animals and brings us the greatest glory to us, it is the spirit that causes all Through our spirit, we will break through the mysteries of knowledge, and we will go deep into it and discover its secrets. (Makaram, 12: 251). Finally, the spirit is to be understood as the source of all our worldly and everlasting matters, It is from the command of Allah, that is, a divine, divine, divine creature and creature, as we have in the narrative, that the soul is from the kingdom of God and from the power of the Almighty God Almighty. It is from the traditions of the prophet's family (AS) that he said: “To us it has come to pass that the soul has been introduced as a creature superior to Gabriel and Michael, who has always been associated with the Prophet (PBUH) and the Imams (PBUH), and that they are in their path to any kind" (Mortar, p. 36, p. 215). It should be noted here that these narratives, not only do not disagree with the interpretation of the Spirit, but are in harmony with them, because the human soul has a degree and degree, That level of the spirit that is in the prophets and the imams is an incredibly high and tremendous order of which it is innocence of error and sin, as well as great knowledge and knowledge, and certainly such a degree of spirit will be superior to all angels, even From Gabriel and Michael, whose angels are barbed. At the end of this section, we will come to the return of the soul and the return of the sure confidence that is clearly stated in the Qur'an, where the Almighty God says: "Sacred soul, and peace be upon you, rejoice and rejoice in the presence of your Lord today" (chapter of Fajr, 28-27). The soul, or the proper soul, finally returns to its original source, which is the essence of the Prophet (Almighty), and this is the approach of existential unity to the issue of being and mankind that can be the axis of unity Islamic thinkers and volunteers. Let's see how Atman's discussion in Upanishads is related or different with the soul in the Holy Qur'an. Atman's consistency and objectivity Which, in addition to the preceding discussions, repeatedly tells us that the true self is the same as God, or that the atman is the same Brahman. In Maha vakia Upanishad, we read that self or soul is God himself who has forgotten his divine truth as a result of blending with unconsciousness or material rushing. The understanding these parallels is the culmination of knowledge and mysticism, and perhaps the ultimate goal of the conduct of the Indian mystics, 
when, in the course of conduct in Sufism and Islamic mysticism, it is said to be fatal, the same as that which was the ultimate goal in Hinduism. Gets Knowledge of Brahman is similar to that in Mandokia Upanishad and other Upanishads, to the seeds of rice or seed of a small stream that is within the heart of man and at the same time is larger than the earth and the sky and the whole world; in the Holy Qur'an, where man from anxiety He says: "Your hearts will not calm down except by the remembrance of Allah, that here is the consistency between the Qur'an and the Upanishads in reference to God Almighty or Brahman." Perhaps they say, "Do not you go to God!" The result of Atman and Brahman's consistency is to recite and indirectly tells us: The presence of divine is in the essence of man.

Another point is that knowing God in the Qur'an and the Upanishads are very similar to each other. In Holy Qur'an; we read in the Holy Qur'an; God is in broken hearts. We also read in the Upanishads in Mandokia that God can be recognized through spiritual and spiritual experience, not through logic and philosophy. As the spirit issue in the Holy Qur'an interacts with the world and the rear of man, in the Upanishads, we clearly find that Atman as the soul or the innermost truth of man as the cosmic spirit or the inner truth of the world in the existence of man is current.

\section{CONCLUSION}

In general, it should be said that the Holy Qur'an used the word "soul" and "soul" repeatedly, mentioning examples of it. In the Holy Quran, the word of soul and soul is used in its philosophical meaning, which is the unified spiritual essence, as in Sura Sajdah, verse 19 or Sura al-Zumar, verse 42. Allah Almighty opens this existential truth at death from man, and brings it to life as a new life and example body, until the Um al-Nashur reaches the end of the grave, from the first to the last, and the size of the building And the world of eternity will receive them forever.

On the other hand, the articles of the Upanishads have also examined the spirituality of the spiritual dimension and the immortality of the soul in various ways, and in the end they have endorsed the eternity of Atman in the permanent attachment to Brahma. In this series of essays, as we read earlier, we read: "The human psyche and the cosmic spirit (Paratmane) are all one single object, and they do not separate." These articles openly refer to the death of the dead and the era of the world (Calpa), and as other Great religions have been emphasized on the resurrection of the dead and the immaterial world. 


\section{REFERENCES}

The Holy Quran.

Abhidananda, Swami. 2003. "Does the Soul Exist After Death?”, internet www.abhedananda.org, Swemi eEdition, Website Akbari, Reza, Immortality, Tehran: Book Boost.

Ayatollahi, Hamid Reza. 1392. Contemporary Religious Studies, Tehran, Research Institute for Humanities and Cultural Studies.

Dasgupta, S.A. 1997. History of Indian Philosophy, Vol. 1, Motile Banarsidass, Delhi.

Dara Shokouh, Mohammad. 2009. Translation of the Upanishads (Sir Akbar), Tehran: Scientific Publication.

Dehghan, Mostafa. 2005. “Nawa and Mikeen's Cup”, articles from The Companions of Javidan's Wisdom, Tehran: Research Institute for Human Sciences.

Emmono, Michelle. 1383. Immortality, translation to Baha'uddin Khoramshahi, Tehran: Nahid.

Gennon, Rennes. 1374. Crossword Meanings, translated by Babak Alikhani, Tehran: Soroush.

Harolda, Krischlow. Comparing Kant's Waggl's Philosophical Perspectives on Religion, translation by Abdol Ali Dastgheib Philosophy Letter, p. 7, p. 122.

Khosrow Panah, Abdul Hussein. 2009. A New Word with Islamic Approach, Qom: Supreme Leader's Office, Vice-Chancellor of Research.

Lahiji, Abdul Razzaq. 1364. Selection of Gohar al-Murad, by Samad Movahed, Tehran: Golshan Printing.

Majlesi, Allameh Mohammad Bagher. 1403. Baharalanvar, Beirut: Darjeeling, $3^{\text {rd }}$ Edition.

Meshkini, Ali. 1367. Evolution in Quran, Qom: Hadi Publishing.

Radhakrishnan, S. 1997. Introduction on The principal Upanishads, Harpocollins, India, Nadia, $5^{\text {th }}$ Impression.

Rezazadeh Shafagh, Sadegh. 1365. Opportunities, Tehran: Scientific and Cultural Publishing.

Sankaracarya.com. 1997. Chandogya Upanishads, trans. Swami Gambhirananda, Advaita Ashrama, Calcutta, $3^{\text {rd }}$ Reprint,.

Stutiey, James and Margaret, A. 1985. Dictionary of Hinduism, Rouledege/Kegan Paul, London: Melbourne and Heleney.

Shawan, Freithoff. 1383. Islam and Wisdom Khaleda, translation of Forouzan Roskhi, Tehran: Hermes. 
Shayegan, Dariush. 2004. Religions and Philosophical Schools of India, Tehran: Amir Kabir.

Tabari, Aby Ja'far Mohammed ibn Jarir. 1362-1382. Jamea al-Bayan Fi Taqsir Al-Quran, Beirut, Lebanon: Dar Al-Ma'arrof.

Tabataba'i, Mohammad Hussein. 1386. Al-Mizan al-Tafsir Al-Quran, Qom: Society of Teachers, Bey. 